\title{
Analysis of interleukin-13 receptor alpha 2 expression as a prognostic biomarker in surgically resected pancreatic cancer patients
}

\author{
Toshio Fujisawa ${ }^{*}$, Takeshi Shimamura², Bharat H Joshi ${ }^{3}$, Raj K Puri ${ }^{3}$ \\ From 30th Annual Meeting and Associated Programs of the Society for Immunotherapy of Cancer (SITC 2015) \\ National Harbor, MD, USA. 4-8 November 2015
}

\section{Background}

IL-13R $\alpha 2$ is recognized as one of the candidate genes significantly associated with pancreatic cancer risk. Previously, we have demonstrated that IL-13R $\alpha 2$ is overexpressed in $\sim 70 \%$ of human pancreatic cancer samples. We have also shown that IL-13 can mediate invasion and metastasis of human pancreatic cancer cells through IL-13R $\alpha 2$ both in vitro and in an in vivo tumor models. Based on these results, we hypothesized that IL-13R $\alpha 2$ expression in pancreatic cancer may be related to overall survival of subjects following surgical resection.

\section{Methods}

Between 1996 and 2012 we obtained 107 samples from NTT Medical Center Tokyo and 129 samples from Yokohama City University Hospital, Japan. Immunohistochemical staining (IHC) for IL-13R $\alpha 2$ was performed and the results analyzed independently by each hospital's pathologists. The level of IL-13R $\alpha 2$ staining intensity $(0$ to $3+)$ was used to categorize the specimens as strong $(2+$ and $3+)$ or weak expressers $(0$ and $1+)$.

\section{Results}

By Kaplan-Meier method, subjects expressing strong IL$13 R \alpha 2$ on their tumors survived significantly shorter duration compared to those with weak expression $(p=0.024)$. Further analysis demonstrated that the level of IL-13R $\alpha 2$ expression was inversely correlated with survival time and invasion, but not with tumor staging and histological grade. We are currently examining the correlation between a variety of other clinical factors and IL-13R $\alpha 2$ expression using Spearman's rank correlation test.

${ }^{1}$ NTT Medical Center Tokyo, Department of Gastroenterology, Tokyo, Japan Full list of author information is available at the end of the article

\section{Conclusions}

In summary, our preliminary results suggest that IL-13R $\alpha 2$ expression has an important role in prognosis and may be critical in overall survival of pancreatic cancer patients.

\section{Authors' details}

${ }^{1} N T T$ Medical Center Tokyo, Department of Gastroenterology, Tokyo, Japan. ${ }^{2}$ Yokohama City University School of Medicine, Department of Oncology, Yokohama, Japan. ${ }^{3}$ Center for Biologics Evaluation \& Research (CBER)/Food \& Drug Administration (FDA), Silver Spring, MD, USA.

Published: 4 November 2015

doi:10.1186/2051-1426-3-S2-P88

Cite this article as: Fujisawa et al: Analysis of interleukin-13 receptor alpha 2 expression as a prognostic biomarker in surgically resected pancreatic cancer patients. Journal for ImmunoTherapy of Cancer 2015 3(Suppl 2):P88.

\section{Submit your next manuscript to BioMed Central and take full advantage of: \\ - Convenient online submission \\ - Thorough peer review \\ - No space constraints or color figure charges \\ - Immediate publication on acceptance \\ - Inclusion in PubMed, CAS, Scopus and Google Scholar \\ - Research which is freely available for redistribution

